\title{
A preliminary study on application of flipped classroom model to English teaching in vocational colleges
}

\author{
Hong Wei $^{1, \text { a }}$ \\ ${ }^{1}$ Shandong Vocational College of Light Industry, Zibo 255300, China \\ a273067030@qq.com
}

Keywords: Flipped classroom; Vocational college; English teaching; Practices

\begin{abstract}
With the implementation of the new curriculum reform, more attention has been paid to the education undertaking. The flipped classroom teaching model is an innovation of the current teaching model. The personalized classroom teaching with students in the center and based on self-study has been increasingly popular among students and teachers. Flipped classroom has promoted the reform of traditional teaching models, and overturned teacher-oriented teaching models. It has been widely applied to classroom teaching practices of various universities and colleges, and achieved satisfying results, greatly improving classroom teaching efficiency, English teaching level and students' learning interest.
\end{abstract}

\section{Introduction}

With the development of science and technology, informationization level and online teaching have made great strides. As a key education department, schools have been greatly impacted by informationization in terms of teaching concepts, teaching design and teaching objectives. It is necessary to change the traditional teaching model, integrate scientific teaching methods into specific teaching practices, focus on realization of the dominant role of students and make them become subjects of classroom teaching. However, flipped classroom has not yet been widely applied to English teaching in China' s vocational colleges. In order to increase the English teaching efficiency of vocational colleges and improve the teaching effect, the English classroom teaching model of vocational colleges should be changed.

\section{Problems existing in English teaching in vocational colleges}

With increasing attention paid to the education undertaking, higher vocational education has achieved remarkable development. English is an important part of teaching in higher vocational colleges. How to increase the English teaching effect has been an issue of common concern to both teachers and students. Therefore, during the exploration process, the following problems might be triggered: To English majors in vocational colleges, English learning is about vocabulary recitation, grammar learning, writing, reading, listening and speaking, thus obscuring their English learning structure and impeding their English learning continuity; to non-English majors, the English knowledge they acquire can hardly meet employment requirements, and their practical English abilities are so poor that they cannot apply their knowledge to practices effectively. Therefore, the current teaching model cannot improve students' English learning performance efficiently nor stimulate their interest in English learning. Besides, under the current English learning model, students have a poor initiative for English learning, thus making efficient English classroom teaching impossible and becoming one of major concerns pushing vocational colleges to address imperatively [1]. 


\section{Significance of flipped classroom}

As a major innovation of current classroom teaching models, flipped classroom teaching model has been widely applied to English teaching in vocational colleges. It has promoted the reform of traditional teaching models, made a breakthrough of English teaching from understanding to cognition and to internalized learning sequence. Teachers and students can interact with each other more often in class, thus realizing students' active learning and dual learning style reform and increasing the English classroom teaching efficiency. The widest application of flipped classroom in English classroom is to input all learning energy to solving learning difficulties at an attempt to increase students' interest in learning English Besides, the application of flipped classroom to English teaching has endowed students with the ability to discover knowledge and choose knowledge which interests them instead of forcing them to learn uninterested knowledge. In this way, students can build their learning motive on self-consciousness and increase their learning motive. During the implementation process, flipped classroom can not only boost the transformation of the teaching model and increase students' English scores, but also develop their ability to actively discover and solve problems. During English teaching in vocational colleges, the application of flipped classroom teaching model can help improve students’ initiative for English learning [2].

\section{Application of flipped classroom teaching model to English teaching}

4.1Implementation of flipped classroom for the improvement of professional English teaching

The flipped classroom teaching model can promote transformation of traditional teaching model. Attention should be paid to the dominant role of students in class, who are expected to raise questions. Before class, teachers should prepare teaching materials and give self-study time to students. Through the flipped classroom teaching model, teachers can solve problems existing in English teaching. Translation is an essential part of English teaching. Teachers should help students master key knowledge points combining the language environment. For example, one lesson was an excerpt from an English film, My Fair Lady. Before interpretation, teachers should display the film to students, which is a major representation of flipped classroom. According to the content of the film works and its background, students can translate the text to deepen their understanding of the text and solve problems with knowledge they acquire [3].

4.2 Improvement of difficult English teaching points through characteristics of flipped classroom

The current English teaching has many problems. Improvement of students' independent study ability is an important task of the current English teaching. During the English teaching in vocational colleges, teachers have adopted diversified teaching models to improve students' English test scores. However, it is hard to improve the efficiency of the current English classroom teaching. To solve difficult English teaching points, it is necessary to give full play to the role of flipped classroom and improve students' problem-raising and problem-solving ability. In flipped classroom, teachers are no longer lecture narrators and students are no longer just learners. The transformation of the two roles can achieve favorable teaching effect. For example, in the English listening class, students should comprehend the content they have heard, make a good record and carry out situationally simulated dialogues to improve students' learning initiative and understanding of content.

4.3 Promotion of English teaching based on advantages of flipped classroom

The flipped classroom teaching model can overturn teaching procedures and develop unparalleled advantages. In flipped classroom, students are subjects, and teachers share resources with students, thus realizing equality and zero-distance communication between students and teachers. Besides, students are allowed to air their opinions. Teachers can guide and summarize students' opinions so as to deepen their understanding of the establishment of students' knowledge system. Moreover, teachers should objectively evaluate students' ideas because students' evaluation has a critical influence on students' learning foundation and capabilities. Through this, English teaching in vocational colleges can achieve further development. For example, after the end of a class, the 
teacher should guide students to summarize students' learning achievements and lead students to correctly regard English knowledge. The learning characteristics of English vocabulary and grammar can help students realize the advantages of the flipped classroom teaching model. Therefore, in the future English teaching, teachers should focus on deepening students understanding of English-speaking countries and their culture, and making of English teaching forms more interesting [4].

\section{Conclusions}

The flipped classroom teaching classroom is a great breakthrough of traditional English teaching models. As a new-type teaching model, it has been widely applied to English teaching to solve existing problems of traditional English teaching, It is worth students' and teachers' try. The flipped classroom teaching model can efficiently spark students' learning interest during the implementation of flipped classroom in English teaching of vocational colleges, and plays an important role in improving the English teaching effect. The author is convinced that, through joint efforts of teachers, English teaching in vocational colleges can achieve long-term development.

\section{References}

[1]ZHANG Yanyan. A preliminary exploration of flipped classroom teaching model for business English majors in vocational colleges: taking Comprehensive English as an example[J]. Science and Technology Innovation Herald,2014,36:146.

[2]CHENLI Ailun. Discussion on teaching design of public English flipped classroom model in vocational colleges[J]. Journal of Wuhan Technical College of Communications,2015,01:51-54. [3]NING Yi, CHA Jing, CHEN Weifeng \& JIN Shanguo. Construction and implementation of flipped classroom foreign language teaching model based on the mobile platform[J]. The Chinese Journal of ICT in Education,2015,06:33-36.

[4]DENG Yumei. Research into public English teaching model construction for vocational colleges based on the independent study theory[D].Guangxi Normal College,2014. 